\title{
Economic Policy Uncertainty and Manufacturing Value-added Exports
}

\author{
Tingting Zhao
}

\author{
School of International Trade and Economics, University of International Business and Economics \\ No.10, Huixin Dongjie, Chaoyang District, Beijing, 100029, China \\ E-mail.melindalanxue@163.com
}

cross'ref http://dx.doi.org/10.5755/j01.ee.33.1.27373

\begin{abstract}
This study explores the effects of increased economic policy uncertainty (EPU) in both importing and exporting countries on manufacturing value-added exports. The results show that increased EPU of both importing and exporting countries would result in decreases in manufacturing value-added trade flows, and the negative effect of exporters' EPU is larger than that of importers' EPU. Our results also provide evidence on the influence channels: increased EPU of exporting countries affects manufacturing value-added trade flows primarily through the cost to export, while increased EPU of importing countries primarily through market demand. This conclusion is robust to a series of robustness checks.
\end{abstract}

Keywords: Economic Policy Uncertainty; Manufacturing Value-Added Exports; Cost to Export; Market Demand.

\section{Introduction}

Increased economic policy uncertainty (EPU) has negative effects on the macroeconomy (Baker et al., 2016; Bloom, 2009). There is a strong negative relationship between uncertainty and trade (Novy \& Taylor, 2020; Taglioni \& Zavacka, 2012). Uncertainty over future trade policies negatively impacts firm import or export behavior (Crowley et al., 2018; Feng et al., 2017; Handley, 2014; Handley \& Limao, 2015, 2017; Imbruno, 2019; Pierce \& Schott, 2016). However, uncertainty related to trade policy comprises a very small share of aggregate EPU (Baker et al., 2016), while fragmentation of production processes across borders has fundamentally altered the nature of international trade (Feenstra, 2010; Kaplan et al., 2018; Timmer et al., 2013). Countries specialize in adding value at particular stages of production and intermediates cross borders several times for further processing. Therefore, conventional indicators of gross exports based on official trade statistics become less informative about how value added is exchanged between countries (Johnson, 2014; Johnson \& Noguera, 2012; Timmer et al., 2013; Wang et al., 2013, 2015).

Gross exports capture not only the domestic value added that is ultimately absorbed abroad (v1), but also the domestic value added that finally returns home (v2), the foreign value-added (v3), as well as double-counted exports (v4) (Koopman et al., 2014; Wang et al., 2013, 2015). The first category "v1" is our dependent variable of interestvalue-added exports, which is labeled as VAX by Johnson \& Noguera (2012). Large differences may exist between gross and value-added exports. Case studies on Apple's iPhone show that, although China appears to be the official exporter of the iPhones to the U.S. according to national customs practices, only a small portion of the value is Chinese value added mainly by assembling and testing activities (Kraemer et al., 2011; Shen \& Silva, 2018; Xing \&

\footnotetext{
${ }^{1}$ According to Kraemer et al. (2011), the value added by Chinese labor is estimated to capture only $1.8 \%$ of the total retail price of the iPhones in 2010. Xing \& Detert (2010) suggest that only about
}

Detert, 2010). ${ }^{1}$ The U.S.-China trade imbalance falls by approximately $30 \%$ to $40 \%$ when measured in value added in 2004 (Johnson \& Noguera, 2012). Value-added exports follow the Heckscher-Ohlin theory more closely than gross exports, as value-added flows capture precisely where production factors are used (Ito et al., 2017). Value-added exports thus capture bilateral trade linkages better than gross exports.

Tam (2018) provides evidence of the significance of EPU in China and the U.S. in influencing global value-added bilateral trade flows. However, to the best of our knowledge, the effect of EPU in importing and exporting countries affects manufacturing value-added trade flows is largely unexplored territory. Hence, we explore the effects of EPU in importing and exporting countries on manufacturing value-added exports and propose possible mechanisms. There are three strands of the novel contributions.

First, we contribute to the literature on how global value-added bilateral trade flows react to EPU shocks. Analyzing how EPU shapes international trade should consider that value-added exports capture bilateral trade linkages better than gross exports. Value-added exports rather than gross exports may help prevent misleading conclusions. Thus, we use the information on bilateral value-added exports rather than on gross exports. Our empirical strategy is to employ a gravity equation, which has been a typical empirical workhorse for analyses of international trade flows for over 50 years (Baier \& Bergstrand, 2007), to estimate the effects of EPU in importing and exporting countries on manufacturing valueadded trade flows. We expect that increased EPU in importing and exporting countries would result in a decrease in manufacturing value-added trade flows.

Second, our work also contributes to the literature on possible channels through which increased EPU affects value-added bilateral trade flows. We suggest that the increased EPU of exporting countries affects manufacturing

$3.6 \%$ of the value of iPhones assembled in China and exported to the U.S. is Chinese value added in 2009. 
value-added trade flows primarily through the cost to export, while increased EPU of importing countries primarily through market demand.

In exporting countries, firms must incur large sunk costs to begin exporting (Roberts \& Tybout, 1997). In particular, studies on uncertainty, such as Dixit (1989), highlight a "wait and see" strategy for firms facing increased uncertainty when investment is irreversible. As the EPU of exporting countries rises, the business environment deteriorates, the external operating risks increase, and thus the external trade costs increase. Thus, firms may adopt a cautious approach, postponing their decision to enter foreign markets. Moreover, importers may raise fears for successful contract enforcement and thus deteriorate exporters' performance (Li, 2021). We expect that increased EPU of exporting countries would result in increased export costs, and thus result in decreases in manufacturing value-added trade flows.

For importing countries, an uncertainty shock acts as a demand shock (Caggiano et al., 2014). As the EPU of importing countries rises, aggregate demand drops, leading firms to be pessimistic about future performance and thus adopt a "wait and see" strategy (Gulen \& Ion, 2016; Stokey, 2016). Demand uncertainty is a key factor in firms' decisionmaking (De Sousa et al., 2020). Research shows that demand uncertainty in destination markets leads to high turnover rates (entry and exit) of firms (Eaton et al., 2008; Kasahara \& Tang, 2019). We expect that increased EPU of importing countries would result in increased destination demand uncertainty, leading firms to be pessimistic about future market demand, and thus result in decreases in manufacturing value-added trade flows.

Third, our study also contributes to the literature on international trade that emphasizes the role of the EPU of exporting countries in value-added bilateral trade flows. Past literature, such as Taglioni \& Zavacka (2012), suggest a strong negative effect of importers' uncertainty but little effect of exporters' uncertainty on bilateral trade flows. However, our work expects different conclusions based on value-added trade statistics. We suggest that the EPU of both importing and exporting countries could influence manufacturing value-added trade flows. Moreover, in some situations, importers' EPU may dampen the intermediate market and domestic investment, and thus lead to more reliance on imports (Sharma \& Paramati, 2021). Hence, we expect a significant negative effect of the EPU of both exporting and importing countries on manufacturing valueadded trade flows. Further, the negative effect of exporters' EPU is expected to be larger than that of importers' EPU.

\section{Methodology and Data}

\section{Methodology}

Our central question is how increased EPU in importing and exporting countries influences value-added bilateral trade flows. Our empirical strategy is to employ a

\footnotetext{
2 The manufacturing value-added bilateral trade flows data are generated from the WIOD 2016 release (Timmer et al., 2015), which consists of a series of databases and covers 28 European Union (EU) countries and 15 other major countries in the world for the period from 2000 to 2014. Data on EPU in importing and exporting countries is obtained from the "Economic Policy Uncertainty" webpage (http://www.policyuncertainty.com/). There are 19 countries that are in
}

traditional log-linear gravity equation with cross-country panel data, using alternative specifications with and without bilateral-sector fixed effects and sector-and-time effects to estimate the effects of EPU in importing and exporting countries on manufacturing value-added trade flows.

The gravity equation has been a typical empirical workhorse for analyses of international trade flows for over 50 years, and convincing empirical evidence suggests that a panel approach could adjust for endogeneity well (Baier \& Bergstrand, 2007). Thus, we construct a panel from 2000 to 2014 of manufacturing value-added exports, exporters' EPU, importers' EPU, and standard gravity equation covariates among 19 potential trading partners, which account for about $70 \%$ of global output on a PPP-adjusted basis ${ }^{2}$.

Unobserved time-invariant bilateral variables are the sources of endogeneity bias in the gravity equation, and they are best controlled for using bilateral fixed effects (Baier \& Bergstrand, 2007; Egger, 2000, 2004). We also use the Hausman test to test for fixed versus random effects and find convincing evidence (the Hausman $\chi^{2}$ statistic is $705.330, p$ $<.01$ ) for the rejection of a random-effects gravity model. Thus, our work applies fixed effects rather than random effects. Bilateral-sector fixed effects $\left(u_{i s j}\right)$ are used to capture all time-invariant bilateral-sector level characteristics, such as bilateral distance, common language, colonial history, and common land border.

It is unobserved time-varying sector-specific factors that may affect manufacturing value-added trade flows in different sectors. This issue can be addressed by controlling for sector-and-time fixed effects (Liu \& Qiu, 2016). To check whether unobserved sector-specific factors would bias our estimates, sector-and-time effects $\left(\lambda_{s t}\right)$ are used to account for all unobserved time-varying sector characteristics, such as a yearly shock to a sector.

Specifically, in a panel context, our empirical model, Equation (1), can be expressed as

$$
\begin{aligned}
& \ln \left(1+V A X_{i s j, t}\right)=\beta_{0}+\beta_{1} \ln E P U_{i, t}+\beta_{2} \ln E P U_{j, t}+ \\
& X_{i j, t}^{1 \prime} \gamma_{1}+X_{i j}^{2 \prime} \gamma_{2}+X_{i, t}^{3 \prime} \gamma_{3}+X_{j, t}^{4 \prime} \gamma_{4}+\varepsilon_{i s j, t},
\end{aligned}
$$

where $\ln V A X_{i s j, t}$ is the natural logarithm of manufacturing value-added exports from sector $s$ in exporter $i$ to importer $j$ in year $t$, and we use the transformed measure, $\ln \left(1+V A X_{i s j, t}\right)$, as our dependent variable to avoid dropping observations of zero value-added trade flows; $\ln E P U_{i, t}$ and $\ln E P U_{j, t}$ are the natural logarithms of EPU in exporter $i$ and importer $j$ in year $t$, respectively; $X_{i j, t}^{1}$ and $X_{i j}^{2}$ are a set of time-varying and time-invariant bilateral characteristics, respectively; $X_{i, t}^{3}$ and $X_{j, t}^{4}$ are a set of timevarying characteristics of exporter $i$ and importer $j$, respectively; and $\varepsilon_{i s j, t}$ is the error term. Standard errors are clustered at the bilateral-sector level to deal with potential heteroskedasticity and serial autocorrelation.

the WIOD 2016 release as well as on the "Economic Policy Uncertainty" webpage, and they account for about $70 \%$ of global output on a PPP-adjusted basis from 2000 to 2014 . Hence, we construct a panel from 2000 to 2014 among 19 potential trading partners - Australia, Brazil, Canada, China, France, Germany, Greece, India, Ireland, Italy, Japan, Mexico, the Netherlands, Russia, South Korea, Spain, Sweden, the United Kingdom, and the United States. 
We control for a set of standard gravity equation covariates according to the standard practice of the gravity equation (Anderson \& Van Wincoop, 2003; Baier \& Bergstrand, 2007, 2009; Egger, 2004; Shi, 2016; Tinbergen, 1962). We control for time-varying bilateral characteristics $\left(X_{i j, t}^{1}\right)$, which include the natural logarithm of the annual bilateral real exchange rate $\left(\ln R E R_{i j, t}\right)$, exchange rate volatility $\left(v \ln E R_{i j, t}\right)$, and a dummy variable for the presence or absence of a free trade agreement $\left(F T A_{i j, t}\right)$. We control for time-invariant bilateral characteristics $\left(X_{i j}^{2}\right)$, which include the natural logarithm of weighted bilateral distance $\left(\operatorname{lndist}_{i j}\right)$, and dummy variables for common language, colonial history, and common land border (comlang com $_{i j}$ colony $_{i j}$, and contig $\left._{i j}\right)$. We control for the time-varying characteristics of exporter $i$ and importer $j\left(X_{i, t}^{3}\right.$ and $\left.X_{j, t}^{4}\right)$, which include the natural logarithm of gross domestic product $(G D P)$ on a PPP-adjusted basis $\left(\ln R G D P_{i, t}\right.$ and $\left.\ln R G D P_{j, t}\right)$, and dummy variables for to be a WTO member or not $\left(W T O_{i, t}\right.$ and $\left.W T O_{j, t}\right)$.

The parameters $\beta_{1}$ and $\beta_{2}$ are of primary interest. A negative sign of $\beta_{1}$ or $\beta_{2}$ indicates that increased EPU in exporting or importing countries would result in decreases in manufacturing value-added trade flows, while a positive sign indicates the opposite effect. Further, a larger absolute value of $\beta_{1}$ than $\beta_{2}$ indicates that the effect of exporters' EPU is larger than that of importers' EPU, while a smaller absolute value of $\beta_{1}$ than $\beta_{2}$ indicates that the effect of exporters' EPU is smaller than that of importers' EPU. After obtaining results from the above empirical model, we test the possible channels, and finally conduct a series of robustness checks to confirm the findings.

\section{Data}

There are two key variables in our empirical model (1): bilateral-sector-level manufacturing value-added exports (dependent variable) and country-level EPU of exporters and importers (the key explanatory variables). There is little endogeneity bias caused by country-level EPU on account of only a few "feedback effects" from bilateral-sector-level value-added exports to country-level EPU.

Value-added exports are a measure of a country's domestic value added that is ultimately absorbed abroad (Koopman et al., 2014; Wang et al., 2013, 2015). The standard Leontief decomposition (Leontief, 1936), which extracts value added from gross exports, is a common method for estimating value-added exports at the country sector or country aggregate level. However, this does not provide a way to decompose intermediate trade flows. Moreover, since 1990, production processes have been internationally fragmented, and intermediates have crossed borders several times for further processing. Therefore, it has become crucial to decompose intermediate trade flows, and the standard Leontief decomposition is not sufficient to uncover the value-added structure of gross trade flows. Koopman et al. (2014) make the first effort in this direction and thus propose a complete accounting framework at the country aggregate level to break up a country's gross exports

\footnotetext{
${ }^{3}$ The WIOD 2016 release (Timmer et al., 2015) consists of a series of databases and covers 56 sectors in 28 EU countries and 15 other
}

into nine value-added and pure double-counted components, which can be conceptually grouped into four buckets: (1) value-added exports, (2) domestic value added that finally returns home, (3) foreign value added that returns to foreign countries, and (4) pure double-counted terms.

However, the accounting framework proposed by Koopman et al. (2014) is valid only at the country aggregate level and does not make a distinction between forward and backward industrial linkages. It is crucial to distinguish between forward and backward industrial linkages at a disaggregated level. Johnson \& Noguera (2012) and Johnson (2014) estimate value-added exports based on forward industrial linkages that capture value added originating from a specific sector via all downstream sectors' gross exports. However, indirect exports through third countries are not reflected in forward-linkage-based calculations. Wang et al. (2013) extend the method of Koopman et al. (2014) and propose an accounting framework that can be used to decompose gross trade flows at a disaggregated level. Compared with forward industrial linkages, backwardlinkage-based value-added exports, which capture value added originating from any domestic sector via backward industrial linkages, are fully consistent with and bounded by gross bilateral trade flows (Wang et al., 2013).

We use the accounting framework initially proposed by Koopman et al. (2014) and further developed by Wang et al. (2013) to decompose bilateral-sector gross exports in the World Input-Output Database (WIOD) 2016 release (Timmer et al., 2015) ${ }^{3}$, and produce a sequence of large panel data sets that reveal the value-added structure based on backward industrial linkages covering 56 sectors in 28 European Union (EU) countries and 15 other major countries worldwide for the period from 2000 to 2014. Appendix A provides details about the countries (Table A1) and sectors (Table A2) of the WIOD 2016 release.

Data on monthly EPU indexes of importing and exporting countries are obtained from the EPU project based on Baker et al. (2016) on the "Economic Policy Uncertainty" webpage 4 . The EPU project builds monthly EPU indexes based on newspaper coverage frequency. The newspaper-based approach first obtains a monthly count of articles that contain a trio of terms about the economy (E), policy $(\mathrm{P})$, and uncertainty $(\mathrm{U})$, and then scales the raw counts, standardizes each monthly newspaper's variation, averages across papers by month, and finally normalizes. Baker et al. (2016) constructed monthly EPU indexes for 15 countries: Australia, Brazil, Canada, China, France, Germany, India, Italy, Japan, Mexico, Russia, South Korea, Spain, the United Kingdom, and the United States. Following the methodology proposed by Baker et al. (2016), other researchers developed additional monthly EPU indexes for Greece, Ireland, the Netherlands, Sweden, and other countries (Armelius et al., 2017; Fountas et al., 2018; Kroese et al., 2015; Zalla, 2017).

There are 19 countries that are both in the WIOD 2016 release and on the EPU webpage, and they account for about $70 \%$ of global output on a PPP-adjusted basis from 2000 to 2014. Our empirical analysis focuses on 19 countries: Australia, Brazil, Canada, China, France, Germany, Greece,

major countries worldwide for the period from 2000 to 2014 4 http://www.policyuncertainty.com/. 
India, Ireland, Italy, Japan, Mexico, the Netherlands, Russia, South Korea, Spain, Sweden, the United Kingdom, and the United States. We focused on the manufacturing sector. Appendix A provides details about the 18 manufacturing sectors of the WIOD 2016 release (Table A3). Since the value-added exports data are at yearly frequency, the country-level EPU data are derived by extracting the arithmetic mean value of the monthly EPU indexes of each country-year cell. The time ranges and data sources of each country-level EPU index are provided in Appendix B.

Our empirical analysis relies on data that includes backward-linkage-based bilateral-sector level manufacturing value-added exports, country-level EPU of exporters and importers, and standard gravity equation covariates. Thus, we merge these datasets manually to construct a panel of 18 manufacturing sectors in the 19 potential trading partners for the period 2000-2014. This effort yields a strongly balanced panel of 6156 bilateral-sectors (19 potential exporters $\times 18$ manufacturing sectors $\times 18$ potential importers) and around 92340 observations $(15$ years $\times 19$ potential exporters $\times 18$ manufacturing sectors $\times 18$ potential importers).

In our mechanism tests, we need to test whether the increased EPU of exporters and importers affects manufacturing value-added trade flows primarily through the cost to export and market demand, respectively. This requires information about the costs of exports and market demand. The cost to export $\left(\right.$ lncost $\left._{i, t}\right)$ is denoted by the natural logarithm of the indicator "cost to export (U.S.\$ per container deflated) (DB06-15 methodology)," 5 which is calculated in U.S. dollars per container deflated based on the methodology in the DB06-15 studies sourced from the World Bank's Doing Business dataset. The market demand $\left(\right.$ demand $\left._{j, t}\right)$ is computed as demand dem $_{t}=100 / B C I_{j, t}$, where $B C I_{j, t}$ denotes the business confidence index (BCI) of the importing country, which is derived by extracting the arithmetic mean value of the monthly business confidence indexes of each country-year cell. The monthly BCI data, where numbers above 100 suggest an increased confidence in near future business performance, and numbers below 100 indicate pessimism toward future performance, are sourced from the Organization for Economic Co-operation and Development dataset. Therefore, demand $_{j, t}$ below 1 suggests increased market demand in the near future, and demand $_{j, t}$ above 1 suggests decreased market demand in the near future. The larger the value of demand $_{j, t}$ is, the weaker the market damand in the near future. Hence, we also merge these two datasets with our unique panel data when we perform our mechanism tests.

The definitions and data sources of the covariates used in this study are listed in Table 1 . The summary statistics for all variables used are shown in Table 2.

Table 1

\section{Definitions and Data Sources of the Covariates}

\begin{tabular}{|c|c|c|}
\hline Variables & Source & Definition \\
\hline$\frac{\ln R G D P_{i, t}}{\ln R G D P}$ & $\begin{array}{l}\text { World Development } \\
\text { Indicators database }\end{array}$ & $\begin{array}{l}\text { The natural logarithm of gross domestic product on a PPP-adjusted basis for exporter } i \text { and } \\
\text { importer } j \text { in year } t \text {, respectively. }\end{array}$ \\
\hline $\ln R E R_{i j, t}$ & $\begin{array}{l}\text { Author's } \\
\text { calculations }\end{array}$ & $\begin{array}{l}\text { The natural logarithm of the annual bilateral real exchange rate }(R E R) . R E R_{i j, t}=N E R_{i j, t} \times \\
C P I_{j, t} / C P I_{i, t}{ }^{6} \text {. }\end{array}$ \\
\hline$v \ln E R_{i j, t}$ & $\begin{array}{l}\text { Author's } \\
\text { calculations }\end{array}$ & $\begin{array}{l}\text { The exchange rate volatility, computed as the yearly standard deviation of monthly log } \\
\text { differences in the nominal exchange rate in line with the concepts and methods established by } \\
\text { Héricourt \& Poncet }(2015)^{7} \text {. }\end{array}$ \\
\hline$F T A_{i j, t}$ & \multirow{7}{*}{$\begin{array}{l}\text { CEPII Gravity } \\
\text { dataset }\end{array}$} & $\begin{array}{l}\text { A dummy variable equal to } 1 \text { if exporter } i \text { and importer } j \text { have a free trade agreement in year } t \text {, } \\
\text { and } 0 \text { otherwise. }\end{array}$ \\
\hline$W T O_{i, t}$ & & A dummy variable equal to 1 if exporter $i$ is a WTO member in year $t$, and 0 otherwise. \\
\hline$W T O_{j, t}$ & & A dummy variable equal to 1 if importer $j$ is a WTO member in year $t$, and 0 otherwise. \\
\hline lndist $_{i j}$ & & $\begin{array}{l}\text { The natural logarithm of the weighted bilateral distance between exporter } i \text { and importer } j \text { in } \\
\text { kilometers (population weighted). }\end{array}$ \\
\hline contig $_{i j}$ & & $\begin{array}{l}\text { A dummy variable equal to } 1 \text { if exporter } i \text { and importer } j \text { share a common land border, and } 0 \\
\text { otherwise. }\end{array}$ \\
\hline comlang $_{i j}$ & & $\begin{array}{l}\text { A dummy variable equal to } 1 \text { if exporter } i \text { and importer } j \text { share a common official or primary } \\
\text { language, and } 0 \text { otherwise. }\end{array}$ \\
\hline colony $_{i j}$ & & $\begin{array}{l}\text { A dummy variable equal to } 1 \text { if exporter } i \text { and importer } j \text { were ever in a colonial relationship, } \\
\text { and } 0 \text { otherwise. }\end{array}$ \\
\hline
\end{tabular}

\footnotetext{
${ }^{5}$ The indicator "cost to export (US\$ per container deflated) (DB0615 methodology)" records the cost associated with exporting a standardized cargo of goods by sea transport through 4 predefined stages: document preparation; customs clearance and inspections; inland transport and handling; and port and terminal handling. All fees charged by government agencies and the private sector to a trader in the process of exporting and importing the goods are considered. These include but are not limited to costs for documents, administrative fees for customs clearance and inspections, customs broker fees, port-related charges, and inland transport costs. Only official costs are recorded.
}

${ }^{6}$ where $R E R_{i j, t}$ indicates the annual bilateral real exchange rate of exporter $i$ and importer $j$ in year $t ; N E R_{i j, t}$ is the annual bilateral nominal exchange rate, sourced from International Financial Statistics (IFS); $C P I_{i, t}$ and $C P I_{j, t}$ are the consumer price index of exporter $i$ and importer $j$ in year $t$, respectively, sourced from the World Bank's World Development Indicators database.

${ }^{7} v \ln E R_{i j, t}=s t d \cdot \operatorname{dev}\left[\ln N E R_{i j, t, m+1}-\ln N E R_{i j, t, m}\right], m=1,2$, ....., 11. $v \ln E R_{i j, t}$ indicates the annual bilateral exchange rate volatility of exporter $i$ and importer $j$ in year $t . \ln N E R_{i j, t, m}$ indicates the natural logarithm of the monthly bilateral nominal exchange rate of exporter $i$ and importer $j$ on month $m$ in year $t$, sourced from IFS. 
Summary Statistics

\begin{tabular}{|c|c|c|c|c|c|}
\hline Variable & Obs. & Mean & Std. Dev. & Min. & Max. \\
\hline $\ln V A X_{i s j, t}$ & 92340 & 3.860 & 2.290 & 0 & 11.27 \\
\hline $\ln E P U_{i, t}$ & 90072 & 4.650 & 0.390 & 3.300 & 5.720 \\
\hline $\ln E P U_{j, t}$ & 90072 & 4.650 & 0.390 & 3.300 & 5.720 \\
\hline lncost $_{i, t}$ & 61560 & 7.070 & 0.400 & 6.280 & 8.490 \\
\hline demand $_{j, t}$ & 92340 & 1 & 0.010 & 0.970 & 1.090 \\
\hline $\ln R G D P_{i, t}$ & 92340 & 28.09 & 1.090 & 25.47 & 30.54 \\
\hline $\ln R G D P_{j, t}$ & 92340 & 28.09 & 1.090 & 25.47 & 30.54 \\
\hline $\ln R E R_{i j, t}$ & 92340 & 0 & 3.050 & -7.680 & 7.680 \\
\hline$v \ln E R_{i j, t}$ & 92340 & 0.020 & 0.010 & 0 & 0.090 \\
\hline$F T A_{i j, t}$ & 92340 & 0.300 & 0.460 & 0 & 1 \\
\hline$W T O_{i, t}$ & 92340 & 0.950 & 0.210 & 0 & 1 \\
\hline$W T O_{j, t}$ & 92340 & 0.950 & 0.210 & 0 & 1 \\
\hline lndistw $_{i j}$ & 92340 & 8.590 & 0.910 & 5.940 & 9.800 \\
\hline contig $_{i j}$ & 92340 & 0.050 & 0.220 & 0 & 1 \\
\hline comlang $_{i j}$ & 92340 & 0.100 & 0.300 & 0 & 1 \\
\hline colony $_{i j}$ & 92340 & 0.060 & 0.230 & 0 & 1 \\
\hline
\end{tabular}

Notes: (1)We use the transformed measure, $\ln \left(1+V A X_{i s j, t}\right)$, as our dependent variable to avoid dropping observations of zero valueadded trade flows. (2) Since EPU data for India and the Netherlands are only available for the period from 2003 to 2014, and EPU data for Spain are only available for the period from 2001 to 2014, there are 2268 missing observations (7 potential exporters or importers $\times$ 18 manufacturing sectors $\times 18$ potential importers or exporters) for $\operatorname{lnEP} U_{i, t}$ and $\operatorname{lnEP} U_{j, t}$, respectively. (3) Since data for lncost ${ }_{i, t}$ is only available for the period from 2005 to 2014, there are 61560 observations (10 years $\times 19$ potential exporters $\times 18$ manufacturing sectors $\times 18$ potential importers) for lncost $_{i, t}$

\section{Results}

\section{Basic Results}

Table 3 provides the empirical results based on our empirical model, Equation (1), using alternative specifications with and without bilateral-sector fixed effects and sector-and-time effects. All estimations show that increased EPU in exporting or importing countries would result in a decrease in manufacturing value-added trade flows. The estimates for the standard gravity equation covariates are consistent with earlier findings (Anderson \& Van Wincoop, 2003; Baier \& Bergstrand, 2007, 2009; Egger, 2004; Shi, 2016; Tinbergen, 1962). In Columns (2) and (3), all time-invariant bilateral-sector level characteristics, such as bilateral distance (lndistw $i j)$, common language (comlang $i j$ ), colonial history $\left(\right.$ colony $\left._{i j}\right)$, and common land border $\left(\right.$ contig $\left.g_{i j}\right)$, are captured by bilateral-sector fixed effects. The coefficients for $\ln E P U_{i, t}$ and $\ln E P U_{j, t}$ in the three columns are all negative and significant, which provides convincing empirical evidence that increased EPU in importing and exporting countries would result in decreases in manufacturing value-added trade flows.

Column (1) provides results without any bilateralsector fixed effects or sector-and-time effects for all 15 years. In Column (1), the absolute value of the coefficient for $\ln E P U_{i, t}$ is smaller than that for $\ln E P U_{j, t}$, suggesting that the effect of exporters' EPU is smaller than that of importers' EPU. However, the explanatory power $\left(R^{2}\right)$ in Column (1) is only $45.5 \%$, which is not sufficiently high. There remain some unobserved time-invariant bilateralsector level characteristics that are the sources of endogeneity bias in the gravity equation, and they are best controlled for using bilateral-sector fixed effects (Baier \& Bergstrand, 2007; Egger, 2000).

Column (2) provides results including bilateral-sector fixed effects, and the explanatory power $\left(R^{2}\right)$ rises to $95.9 \%$ (within $R^{2}=27.9 \%$ ). In Column (2), the absolute value of the coefficient for $\ln E P U_{i, t}$ is larger than that for $\ln E P U_{j, t}$, suggesting that the negative effect of exporters' EPU is larger than that of importers' EPU. However, considerable time-varying sector characteristics may also bias our estimates. This issue can be addressed by controlling for sector-and-time fixed effects (Liu \& Qiu, 2016). Column (3) provides the results using both bilateral-sector fixed effects and sector-and-time effects, and the explanatory power $\left(R^{2}\right)$ in Column (3) rises to $96.4 \%$ (within $R^{2}=14.1 \%$ ). In Column (3), the absolute value of the coefficient for $\ln E P U_{i, t}$ is larger than that for $\ln E P U_{j, t}$, which provides convincing empirical evidence that the negative effect of exporters' EPU is larger than that of importers' EPU.

In summary, we find convincing empirical evidence that increased EPU in importing and exporting countries would result in decreases in manufacturing value-added trade flows, and the negative effect of exporters' EPU is larger than that of importers' EPU. 
Basic Results

\begin{tabular}{|c|c|c|c|}
\hline Variable & $\begin{array}{l}\text { (1) No bilateral-sector or } \\
\text { sector-and-time fixed effects }\end{array}$ & $\begin{array}{l}\text { (2) With bilateral-sector fixed } \\
\text { effects }\end{array}$ & $\begin{array}{l}\text { (3) With bilateral-sector and } \\
\text { sector-and-time fixed effects }\end{array}$ \\
\hline $\ln E P U_{i, t}$ & $\begin{array}{c}-0.133 * * * \\
(-4.5748)\end{array}$ & $\begin{array}{l}-0.143 * * * \\
(-13.4882)\end{array}$ & $\begin{array}{c}-0.123 * * * \\
(-9.1845)\end{array}$ \\
\hline $\ln E P U_{j, t}$ & $\begin{array}{c}-0.160 * * * \\
(-6.0746)\end{array}$ & $\begin{array}{c}-0.055 * * * \\
(-5.3508)\end{array}$ & $\begin{array}{l}-0.035 * * * \\
(-2.9244)\end{array}$ \\
\hline $\ln R G D P_{i, t}$ & $\begin{array}{l}0.990 * * * \\
(50.8116)\end{array}$ & $\begin{array}{l}0.708^{* * *} \\
(22.9484)\end{array}$ & $\begin{array}{l}1.140 * * * \\
(27.3958)\end{array}$ \\
\hline $\ln R G D P_{j, t}$ & $\begin{array}{l}0.743 * * * \\
(38.0928)\end{array}$ & $\begin{array}{l}0.639 * * * \\
(22.4917)\end{array}$ & $\begin{array}{l}1.071 * * * \\
(28.4523)\end{array}$ \\
\hline $\ln R E R_{i j, t}$ & $\begin{array}{c}-0.007 \\
(-0.9394)\end{array}$ & $\begin{array}{c}0.008 \\
(1.6404)\end{array}$ & $\begin{array}{c}0.008 * \\
(1.6897)\end{array}$ \\
\hline$v \ln E R_{i j, t}$ & $\begin{array}{c}-8.922 * * * \\
(-8.2391)\end{array}$ & $\begin{array}{c}0.709 * * * \\
(3.0416)\end{array}$ & $\begin{array}{c}-1.687 * * * \\
(-5.9046)\end{array}$ \\
\hline$F T A_{i j, t}$ & $\begin{array}{l}0.114 * * \\
(1.9691)\end{array}$ & $\begin{array}{c}0.011 \\
(0.4918)\end{array}$ & $\begin{array}{c}0.130 * * * \\
(5.7502)\end{array}$ \\
\hline$W T O_{i, t}$ & $\begin{array}{l}2.235^{* * *} \\
(21.9624)\end{array}$ & $\begin{array}{l}0.090^{* * *} \\
(3.1765)\end{array}$ & $\begin{array}{l}0.060^{* *} \\
(2.2904)\end{array}$ \\
\hline$W T O_{j, t}$ & $\begin{array}{l}1.045^{* * *} \\
(11.3975)\end{array}$ & $\begin{array}{l}0.188^{* * *} \\
(7.5242)\end{array}$ & $\begin{array}{l}0.159^{* * *} \\
(6.4478)\end{array}$ \\
\hline lndistw $_{i j}$ & $\begin{array}{l}-0.924 * * * \\
(-29.4063)\end{array}$ & & \\
\hline contig $_{i j}$ & $\begin{array}{l}0.399 * * * \\
(3.7427)\end{array}$ & & \\
\hline comlang $_{i j}$ & $\begin{array}{l}0.424 * * * \\
(5.3074)\end{array}$ & & \\
\hline colony $_{i j}$ & $\begin{array}{c}0.158 \\
(1.6179)\end{array}$ & & \\
\hline Constant & $\begin{array}{l}-38.563 * * * \\
(-50.5083)\end{array}$ & $\begin{array}{l}-33.312 * * * \\
(-55.9022)\end{array}$ & $\begin{array}{l}-57.733 * * * \\
(-34.1617)\end{array}$ \\
\hline bilateral-sector fixed effects & No & Yes & Yes \\
\hline sector-and-time effects & No & No & Yes \\
\hline$R^{2}$ & 0.455 & 0.959 & 0.964 \\
\hline adjusted $R^{2}$ & 0.455 & 0.956 & 0.961 \\
\hline within $R^{2}$ & & 0.279 & 0.141 \\
\hline adjusted within $R^{2}$ & & 0.279 & 0.141 \\
\hline Observations & 87984 & 87984 & 87984 \\
\hline
\end{tabular}

Notes: $t$-statistics are shown in parentheses. ${ }^{*} p<.1,{ }^{* *} p<.05,{ }^{* * *} p<.01$. Standard errors are clustered at the bilateral-sector level. Coefficient estimates for various bilateral-sector/sector-and-time fixed effects are not reported for brevity. Since EPU data for India and the Netherlands are only available for the period from 2003 to 2014, and EPU data for Spain are only available for the period from 2001 to 2014, there are 4356 missing observations. ${ }^{8}$. Hence, there were only 87984 observations in the regression analysis.

\section{Mechanism Test}

Why does increased EPU in importing and exporting countries decrease manufacturing value-added trade flows? Why is the negative effect of exporters' EPU larger than that of importers' EPU? To understand these interesting observations, we tested possible channels. We suggest that the increased EPU of exporting countries affects manufacturing value-added trade flows primarily through the cost to export, while increased EPU of importing countries primarily through market demand.
Table 4 provides the mechanism test results using both the bilateral-sector fixed effects and sector-and-time effects. All the results in Columns (1)-(6) are with the standard gravity equation covariates being controlled for, and the explanatory power $\left(R^{2}\right)$ generally ranges from 96.2 to $97.4 \%$ (within $R^{2}$ generally ranges from $10.2 \%$ to $14.3 \%$ ).

Column (1) shows the results. We find a significant and negative estimate for $\ln E P U_{i, t}$ and $\ln E P U_{j, t}$, respectively, and the absolute value of the coefficient for $\ln E P U_{i, t}$ is larger than that for $\ln E P U_{j, t}$. This indicates that increased

\footnotetext{
${ }^{8}$ There are 1836 missing observations in the year 2000: 3 potential exporters $\times 18$ manufacturing sectors $\times 18$ potential importers +3 potential importers $\times 18$ manufacturing sectors $\times 16$ potential exporters. There are 1260 missing observations in the years 2001 and 2002, respectively: 2 potential exporters $\times 18$ manufacturing sectors $\times 18$ potential importers +2 potential importers $\times 18$ manufacturing sectors $\times 17$ potential exporters.
} 
EPU in importing and exporting countries would result in decreases in manufacturing value-added trade flows, and the negative effect of exporters' EPU is larger than that of importers' EPU.

In Columns (2) and (6), we only include the cost to export $\left(\right.$ lncost $\left._{i, t}\right)$ and the market demand $\left(\right.$ demand $\left._{j, t}\right)$ that may influence manufacturing value-added trade flows, respectively. In Column (2), the coefficient of lncost $_{i, t}$ is negative and significant, indicating that an increase in the cost of exports leads to a significant decrease in manufacturing value-added trade flows. In Column (6), we find a negative and significant estimate for demand $_{j, t}$ as well, indicating that a decline in market damand leads to a significant decrease in manufacturing value-added trade flows ${ }^{9}$.

In Column (3), we include $\ln E P U_{i, t}, \ln E P U_{j, t}$,

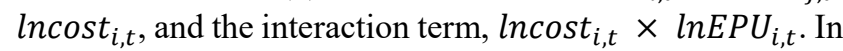
Column (5), we include $\ln E P U_{i, t}, \ln E P U_{j, t}$, demand dem, $_{j, t}$, and the interaction term, demand det, $\times \ln E P U_{j, t}$. In Column (4), we include $\ln E P U_{i, t}, \ln E P U_{j, t}$, lncost $_{i, t}$, demand $_{j, t}$,

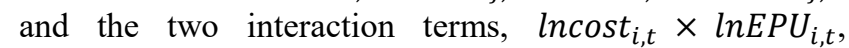
demand $_{j, t} \times \operatorname{lnEP} U_{j, t}$ simultaneously.

Clearly, the coefficients of lncost $_{i, t} \times \operatorname{lnEP} U_{i, t}$ in Columns (3) and (4), and the coefficients of demand det, $\times$ $\operatorname{lnEPU_{j,t}}$ in Columns (4) and (5) are all negative and significant $(\mathrm{p}<.01)$. The tests suggest that manufacturing value-added trade flows decrease in response to increased EPU of exporting countries when the costs of exports increase and manufacturing value-added trade flows decrease in response to increased EPU of importing countries when market demand weakens. This confirms the conjecture that increased EPU of exporting countries affects manufacturing value-added trade flows primarily through the cost to export, while increased EPU of importing countries primarily through market demand.

The coefficients of $\ln E P U_{i, t}$ in Columns (3) and (4) become positive and significant $(\mathrm{p}<.05)$, indicating that in some situations, increased EPU of exporting countries may lead to more exports. A possible reason is that in some situations, as the EPU of exporting countries rises, domestic demand drops (Caggiano et al., 2014), forcing firms to seek business opportunities abroad. The coefficients of $\ln E P U_{j, t}$ in Columns (4) and (5) become positive and significant ( $p$ $<.01$ ), indicating that in some situations, increased EPU of importing countries may lead to more imports. A possible reason is that in some situations, importers' EPU may dampen the intermediate market and domestic investment, and thus lead to more reliance on imports (Sharma \& Paramati, 2021). The values of the coefficients for $\ln E P U_{i, t}$ in Columns (3) and (4) are all smaller than those of the coefficients for $\operatorname{lnEP} U_{j, t}$ in Columns (4) and (5), and the statistical significance of the coefficients for $\ln E P U_{i, t}$ in Columns (3) and (4) are all lower than those of the coefficients for $\operatorname{lnEP} U_{j, t}$ in Columns (4) and (5). Therefore, the positive part of the effect of exporters' EPU is smaller than that of importers' EPU. This provides a convincing explanation for why the total negative effect of exporters' EPU is larger than that of importers' EPU.

In summary, we find convincing empirical evidence that increased EPU of exporting countries affects manufacturing value-added trade flows primarily through the cost to export, while increased EPU of importing countries primarily through market demand. We also provide a convincing explanation for why the total negative effect of exporters' EPU is larger than that of importers' EPU.

Table 4

Mechanism Test

\begin{tabular}{|c|c|c|c|c|c|c|}
\hline \multirow{2}{*}{ Variable } & \multicolumn{6}{|c|}{$\ln \left(1+V A X_{i s j, t}\right)$} \\
\hline & (1) & (2) & (3) & (4) & (5) & (6) \\
\hline $\ln E P U_{i, t}$ & $\begin{array}{c}-0.123 * * * \\
(-9.1845)\end{array}$ & & $\begin{array}{l}0.129 * * \\
(2.1652)\end{array}$ & $\begin{array}{l}0.126 * * \\
(2.1216)\end{array}$ & $\begin{array}{l}-0.116^{* * *} \\
(-8.7484)\end{array}$ & \\
\hline $\ln E P U_{j, t}$ & $\begin{array}{l}-0.035 * * * \\
(-2.9244)\end{array}$ & & $\begin{array}{c}-0.026^{*} \\
(-1.9340)\end{array}$ & $\begin{array}{c}0.415 * * * \\
(7.7901)\end{array}$ & $\begin{array}{l}0.494 * * * \\
(10.3887)\end{array}$ & \\
\hline $\operatorname{lncost}_{i, t}$ & & $\begin{array}{l}-0.084 * * \\
(-1.9893)\end{array}$ & $\begin{array}{c}-0.055 \\
(-1.3897)\end{array}$ & $\begin{array}{c}-0.056 \\
(-1.4156)\end{array}$ & & \\
\hline $\operatorname{lncost}_{i, t} \times \ln E P U_{i, t}$ & & & $\begin{array}{l}-0.029 * * * \\
(-3.5013)\end{array}$ & $\begin{array}{l}-0.028 * * * \\
(-3.4589)\end{array}$ & & \\
\hline demand $_{j, t}$ & & & & $\begin{array}{c}0.766^{* * *} \\
(3.7378)\end{array}$ & $\begin{array}{c}-0.134 \\
(-0.6336)\end{array}$ & $\begin{array}{c}-0.927 * * * \\
(-4.1015)\end{array}$ \\
\hline $\operatorname{demand}_{j, t} \times \ln E P U_{j, t}$ & & & & $\begin{array}{c}-0.428 * * * \\
(-8.5996)\end{array}$ & $\begin{array}{l}-0.528 * * * \\
(-11.7804)\end{array}$ & \\
\hline Controls & Yes & Yes & Yes & Yes & Yes & Yes \\
\hline bilateral-sector fixed effects & Yes & Yes & Yes & Yes & Yes & Yes \\
\hline sector-and-time effects & Yes & Yes & Yes & Yes & Yes & Yes \\
\hline$R^{2}$ & 0.964 & 0.972 & 0.974 & 0.974 & 0.965 & 0.962 \\
\hline adjusted $R^{2}$ & 0.961 & 0.969 & 0.971 & 0.971 & 0.963 & 0.959 \\
\hline
\end{tabular}

\footnotetext{
${ }^{9}$ As mentioned before, the larger the value of demand $_{j, t}$ is, the weaker the market damand in the near future will be.
} 
Tingting Zhao. Economic Policy Uncertainty and Manufacturing Value-added Exports

\begin{tabular}{|c|c|c|c|c|c|c|}
\hline \multirow{2}{*}{ Variable } & \multicolumn{7}{|c|}{$\ln \left(\mathbf{1}+\boldsymbol{V} \boldsymbol{A} \boldsymbol{X}_{\boldsymbol{i s j}, \boldsymbol{t}}\right)$} & $\mathbf{( 4 )}$ & $\mathbf{( 5 )}$ & $\mathbf{( 6 )}$ \\
\cline { 2 - 8 } & $\mathbf{( 1 )}$ & $\mathbf{( 2 )}$ & $\mathbf{( 3 )}$ & 0.103 & 0.143 & 0.142 \\
\hline within $R^{2}$ & 0.141 & 0.105 & 0.102 & 0.103 & 0.142 & 0.142 \\
\hline adjusted within $R^{2}$ & 0.141 & 0.105 & 0.101 & 55404 & 83664 & 92340 \\
\hline Observations & 87984 & 61560 & 55404 & 554
\end{tabular}

Notes: $t$-statistics are shown in parentheses. ${ }^{*} p<.1, * * p<.05, * * *<.01$. Standard errors are clustered at the bilateral-sector level. Coefficient estimates for control variables, various bilateral-sector fixed effects, and sector-and-time effects are not reported for brevity. To avoid possible interference with the estimation results caused by the simultaneous response problem, lncost $t_{i, t}$ and demand $d_{j, t}$ in the interaction terms are taken as lagged levels ( lncost $_{i, t-1}$ and demand dit-1 $_{j}$ ).

\section{Robustness Checks}

We conducted a series of robustness checks to confirm our findings. The results are reported in Table 5, confirming that our key findings remain robust.

Columns (1) and (2) show that our results are robust when using alternative estimation methods. In our basic empirical model, we use the ordinary least squares (OLS) method to estimate the effects of EPU in importing and exporting countries on manufacturing value-added trade flows. Although we use the transformed measure, $\ln (1+$ $\left.V A X_{i s j, t}\right)$, as our dependent variable to avoid dropping observations of zero value-added trade flows, the OLS method may still yield biased and inconsistent coefficient estimates because of the problem of many zero-value observations. We used alternative estimation methods to verify our results. First, we use the Poisson pseudomaximum-likelihood (PPML) estimator, which provides a natural way to deal with zero values of the dependent variable (Silva \& Tenreyro, 2006). Column (1) provides the PPML-estimated results using both bilateral-sector fixed effects and sector-and-time effects. Since there are 1375 observations dropped, which are either singletons or separated by a fixed effect, only 86609 observations remain in the regression analysis. Second, we use the Tobit estimator to deal with zero values of the dependent variable. Column (2) provides Tobit-estimated results with random effects. The PPML-estimated and Tobit-estimated coefficients for $\ln E P U_{i, t}$ and $\ln E P U_{j, t}$ remain negative and significant, and the absolute values of the PPML-estimated and Tobit-estimated coefficients for $\ln E P U_{i, t}$ are larger than those for $\ln E P U_{j, t}$ respectively. This indicates that our findings are robust to the use of alternative estimation methods.

Column (3) shows that our results are robust when using instrumental variables (IV). While there is little endogeneity bias caused by country-level EPU on account of only a few "feedback effects" from bilateral-sector level value-added exports to country-level EPU, we still use an IV estimation to address the endogeneity bias of the country-level EPU in our model. We use the two lagged levels of country-level EPU as instruments. That is, we use $\ln E P U_{i, t-1}$ and $\ln E P U_{i, t-2}$ as instruments of $\ln E P U_{i, t}$, and we take $\ln E P U_{j, t-1}$ and $\ln E P U_{j, t-2}$ as instruments of $\ln E P U_{j, t}$. Column (3) provides IV-estimated results using both bilateral-sector fixed effects and sector-and-time effects, which are obtained using the two-stage least squares method. The under-identification test shows that the instruments are correlated with the trends of the EPU of importing and exporting countries (the Kleibergen-Paap rk LM statistic is $2898.315, \mathrm{p}<.001$ ). The weak identification test shows that there are no weak instruments (the Kleibergen-Paap rk Wald F statistic is 5970.745). The overidentification test provides empirical support that the instruments are exogenous to the error terms of our empirical model (the Hansen J statistic is $1.538, \mathrm{p}=0.463$ ). All three tests suggest that the instruments are suitable; thus, the IV estimates are reliable. The IV-estimated coefficients for $\ln E P U_{i, t}$ and $\ln E P U_{j, t}$ remain negative and significant, and the absolute value of the IV-estimated coefficient for $\ln E P U_{i, t}$ is larger than that for $\ln E P U_{j, t}$. This indicates that our findings are robust to the use of instrumental variables.

Columns (4) and (5) show that our results are robust when using alternative measures of the key explanatory variables. Since the value-added exports data are at yearly frequency, in the main analysis, the country-level EPU data are derived by extracting the arithmetic mean value of the monthly EPU indexes of each country-year cell. In this robustness check, we use alternative measures for the key explanatory variables. First, we obtain country-level EPU data by extracting the geometric mean value of the monthly EPU indexes of each country-year cell. The results are reported in Column (4). Second, we obtain country-level EPU data by extracting the median mean value of the monthly EPU indexes of each country-year cell. The results are reported in Column (5). The coefficients in Columns (4) and (5) for $\ln E P U_{i, t}$ and $\ln E P U_{j, t}$ remain negative and significant, and the absolute values of the coefficients for $\ln E P U_{i, t}$ are larger than those for $\ln E P U_{j, t}$ respectively. This indicates that our findings are robust to the use of alternative measures of key explanatory variables.

Robustness Checks

Table 5

\begin{tabular}{|l|c|c|c|c|c|}
\hline \multicolumn{1}{|c|}{ Variable } & $\mathbf{( 1 ) P P M L}$ & $\mathbf{( 2 ) T o b i t}$ & $\mathbf{( 3 ) 2 S L S}$ & $\mathbf{( 4 ) O L S}$ & $\mathbf{( 5 ) O L S}$ \\
\hline $\ln E P U_{i, t}$ & $-0.044^{* * *}$ & $-0.145^{* * *}$ & $-0.222^{* * *}$ & $-0.126^{* * *}$ & $-0.128^{* * *}$ \\
& $(-10.5591)$ & $(-26.9290)$ & $(-10.0039)$ & $(-9.4164)$ & $(-9.8060)$ \\
\hline $\ln E P U_{j, t}$ & $-0.006 *$ & $-0.063 * * *$ & $-0.054 * * *$ & $-0.039 * * *$ & $-0.028^{* *}$ \\
& $(-1.8678)$ & $(-11.7362)$ & $(-2.6567)$ & $(-3.2007)$ & $(-2.3823)$ \\
\hline Controls & Yes & Yes & Yes & Yes & Yes \\
\hline
\end{tabular}


Inzinerine Ekonomika-Engineering Economics, 2022, 33(1), 103-114

\begin{tabular}{|l|c|c|c|c|c|}
\hline \multicolumn{1}{|c|}{ Variable } & (1)PPML & (2)Tobit & (3)2SLS & (4)OLS & (5)OLS \\
\hline bilateral-sector fixed effects & Yes & No & Yes & Yes & Yes \\
\hline sector-and-time effects & Yes & No & Yes & Yes & Yes \\
\hline$R^{2}$ & & & & 0.964 & 0.964 \\
\hline adjusted $R^{2}$ & & & & 0.961 & 0.961 \\
\hline within $R^{2}$ & & & & 0.142 & 0.142 \\
\hline adjusted within $R^{2}$ & & & & 0.141 & 0.142 \\
\hline Pseudo $R^{2}$ & 0.319 & & & & \\
\hline Kleibergen-Paap rk LM statistic & & & 2898.315 & & \\
P-val & & & 0.000 & & \\
\hline Kleibergen-Paap rk Wald F statistic & & & 1.5970 .745 & & \\
\hline Hansen J statistic & & & 0.463 & & \\
P-val & & & 75672 & 87984 & 87984 \\
\hline Observations & 86609 & 87984 & &
\end{tabular}

Notes: $t$-statistics are shown in parentheses. ${ }^{*} p<.1,{ }^{* *} p<.05,{ }^{* * *} p<.01$. Standard errors are clustered at the bilateral-sector level. Coefficient estimates for control variables, various bilateral-sector fixed effects, and sector-and-time effects are not reported for brevity. In Column (4), the country-level EPU data are derived by extracting the geometric mean value of the monthly EPU indexes of each country-year cell. In Column (5), the country-level EPU data are derived by extracting the median mean value of the monthly EPU indexes of each country-year cell.

\section{Conclusion}

The effects of EPU on trade have long been a hot topic in both academic and policy circles. Value-added exports capture bilateral trade linkages better than gross exports. This study investigates the effects of EPU in importing and exporting countries on manufacturing value-added exports and proposes possible mechanisms that contribute to the emerging literature on how global value-added bilateral trade flows react to EPU shocks.

We use the accounting framework initially proposed by Koopman et al. (2014) and further developed by Wang et al. (2013) to decompose bilateral-sector gross exports in the WIOD 2016 release (Timmer et al., 2015), and thus obtain data on backward-linkage-based bilateral-sector level manufacturing value-added exports. Data on monthly EPU indexes of importing and exporting countries are obtained from the EPU project based on Baker et al. (2016) on the "Economic Policy Uncertainty" webpage, and we derive the country-level EPU data by extracting the arithmetic mean value of the monthly EPU indexes of each country-year cell. We also included a set of standard gravity equation covariates. We merge these datasets manually to construct a panel of 18 manufacturing sectors in the 19 potential trading partners for the period 2000-2014.

We employ a traditional log-linear gravity equation using alternative specifications with and without bilateralsector fixed effects and sector-and-time effects, finding that increased EPU in importing and exporting countries would result in decreases in manufacturing value-added trade flows, and the negative effect of exporters' EPU is larger than that of importers' EPU. The results are robust to a series of robustness checks and are essentially consistent with the literature on uncertainty and trade.

We also propose and test possible channels through which increased EPU affects value-added bilateral trade flows. Past literature, such as Taglioni \& Zavacka (2012), suggest a strong negative effect of importers' uncertainty but little effect of exporters' uncertainty on bilateral trade flows. We find convincing empirical evidence that increased EPU of exporting countries affects manufacturing value-added trade flows primarily through the cost to export, while increased EPU of importing countries primarily through market demand. We also provide a convincing explanation for why the total negative effect of exporters' EPU is larger than that of importers' EPU. The mechanism test shows that the positive part of the effect of exporters' EPU is smaller than that of importers' EPU. This is consistent with the findings of Sharma \& Paramati (2021) — in some situations, importers' EPU may dampen the intermediate market and domestic investment, and thus lead to more reliance on imports.

Concerning policy implications, this study supports the view that increased EPU of exporting and importing countries would result in a "lose-lose" situation for both countries. A country would fall into a situation of both dipping exports and imports owing to increased EPU, and the exports would fall at far greater rates than imports, likely leading to an economic recession. There has been resurging trade protectionism for the post-2008 global financial crisis period, implying rising uncertainty surrounding the future of the world trading system. Policymakers in both exporting and importing countries should deescalate trade tensions and uncertainties in their economic policies. The lower the tension between exporting and importing countries, the higher the volumes of global value-added bilateral trade flows. Decreased EPU in a country would help boost exports and imports, especially exports.

The manufacturing value-added exports in our study include indirect exports through third countries; that is, the domestic value added that is ultimately absorbed in third countries. Therefore, the effects of EPU in importing and exporting countries on manufacturing value-added bilateral trade flows may be influenced by the factors of third countries. That is, interactive effects may not be addressed in this study to limit its scope. This topic is left for future research. 


\section{References}

Anderson, J. E., \& Van Wincoop, E. (2003). Gravity with gravitas: A solution to the border puzzle. American Economic Review, 93(1), 170-192. https://www.jstor.org/stable/3132167; https://doi.org/10.1257/000282803321455214

Arbatli, E. C., Davis, S. J., Ito, A., et al. (2017). Policy uncertainty in Japan. IMF Working Paper, No.17/128. https://www.imf.org/en/Publications/WP/Issues/2017/05/30/Policy-Uncertainty-in-Japan-44915; https://doi.org/10.3 $386 /$ w23411

Armelius, H., Hull I., \& Stenbacka, K. H. (2017). The timing of uncertainty shocks in a small open economy. Economics Letters, 155, 31-34. https://doi.org/10.1016/j.econlet.2017.03.016

Baier, S. L., \& Bergstrand, J. H. (2007). Do free trade agreements actually increase members' international trade? Journal of International Economics, 71(1), 72-95. https://doi.org/10.1016/j.jinteco.2006.02.005

Baier, S. L., \& Bergstrand, J. H. (2009). Estimating the effects of free trade agreements on international trade flows using matching econometrics. Journal of International Economics, 77(1), 63-76. https://doi.org/10.1016/j.jinteco. 2008.09.006

Baker, S. R., Bloom, N., \& Davis, S. J. (2016). Measuring economic policy uncertainty. Quarterly Journal of Economics, 131(4), 1593-1636. https://doi.org/10.1093/qje/qjw024

Bloom, N. (2009). The impact of uncertainty shocks. Econometrica, 77(3), 623-685. https://doi.org/10.3982/ECTA6248

Caggiano, G., Castelnuovo, E., \& Groshenny, N. (2014). Uncertainty shocks and unemployment dynamics in U.S. Recessions. Journal of Monetary Economics, 67, 78-92. https://doi.org/10.1016/j.jmoneco.2014.07.006

Crowley, M., Meng, N., \& Song, H. (2018). Tariff scares: Trade policy uncertainty and foreign market entry by Chinese firms. Journal of International Economics, 114, 96-115. https://doi.org/10.1016/j.jinteco.2018.05.003

De Sousa, J., Disdier, A. C., \& Gaigne, C. (2020). Export decision under risk. European Economic Review, $121,103342$. https://doi.org/10.1016/j.euroecorev.2019.103342

Dixit, A. (1989). Entry and exit decisions under uncertainty. Journal of Political Economy, 97(3), 620-638. https://doi.org/10.1086/261619

Eaton, J., Eslava, M., Kugler, M., et al. (2008). Export dynamics in Colombia: Firm-level evidence In E. Helpman, D. Marin, \& T. Verdier (Ed.), The organization of firms in a global economy (pp. 231-272). Cambridge, Massachusetts \& London, England: Harvard University Press. https://doi.org/10.32468/be.522

Egger, P. (2000). A note on the proper econometric specification of the gravity equation. Economics Letters, 66(1), 25-31. https://doi.org/10.1016/S0165-1765(99)00183-4

Egger, P. (2004). Estimating regional trading bloc effects with panel data. Review of World Economics, 140(1), 151-166 https://www.jstor.org/stable/40440998; https://doi.org/10.1007/BF02659714

Feenstra, R. C. (2010). Offshoring in the global economy: Microeconomic structure and macroeconomic implications. Cambridge, MA: MIT Press.

Feng, L., Li, Z., \& Swenson, D. L. (2017). Trade policy uncertainty and exports: Evidence from China's WTO accession. Journal of International Economics, 106, 20-36. https://doi.org/10.1016/j.jinteco.2016.12.009

Fountas, S., Karatasi, P., \& Tzika, P. (2018). Economic policy uncertainty in Greece: Measuring uncertainty for the Greek macroeconomy. South-Eastern Europe Journal of Economics, 16(1), 79-92. http://www.asecu.gr/Seeje/issue30/ issue30-fountas-karatasi-tzika.pdf

Gulen, H., \& Ion, M. (2016). Policy uncertainty and corporate investment. Review of Financial Studies, 29(3), 523-564. https://www.jstor.org/stable/43866019

Handley, K. (2014). Exporting under trade policy uncertainty: Theory and evidence. Journal of International Economics, 94(1), 50-66. https://doi.org/10.1016/j.jinteco.2014.05.005

Handley, K., \& Limao, N. (2015). Trade and investment under policy uncertainty: Theory and firm evidence. American Economic Journal: Economic Policy, 7(4), 189-222. https://doi.org/10.1257/pol.20140068

Handley, K., \& Limao, N. (2017). Policy uncertainty, trade, and welfare: Theory and evidence for China and the United States. American Economic Review, 107(9), 2731-2783. https://doi.org/10.1257/aer.20141419

Hericourt, J., \& Poncet, S. (2015). Exchange rate volatility, financial constraints, and trade: Empirical evidence from Chinese firms. World Bank Economic Review, 29(3), 550-578. https://doi.org/10.1093/wber/lht035

Imbruno, M. (2019). Importing under trade policy uncertainty: Evidence from China. Journal of Comparative Economics, 47(4), 806-826. https://doi.org/10.1016/j.jce.2019.06.004

Ito, T., Rotunno, L., \& Vezina, P. L. (2017). Heckscher-Ohlin: Evidence from virtual trade in value added. Review of International Economics, 25(3), 427-446. https://doi.org/10.1111/roie.12230 
Johnson, R. C. (2014). Five facts about value-added exports and implications for macroeconomics and trade research. Journal of Economic Perspectives, 28(2), 119-142. http://www.jstor.org/stable/23723487; https://doi.org/10.12 57/jep.28.2.119

Johnson, R. C., \& Noguera, G. (2012). Accounting for intermediates: Production sharing and trade in value added. Journal of International Economics, 86(2), 224-236. https://doi.org/10.1016/j.jinteco.2011.10.003

Kaplan, L. C., Kohl, T., \& Martinez-Zarzoso, I. (2018). Supply-chain trade and labor market outcomes: The case of the 2004 European Union enlargement. Review of International Economics, 26(2), 481-506. https://doi.org/10.111 $1 /$ roie. 12339

Kasahara, H., \& Tang, H. (2019). Excessive entry and exit in export markets. Journal of the Japanese and International Economies, 53, 101031. https://doi.org/10.1016/j.jjie.2019.101031

Koopman, R., Wang, Z., \& Wei, S. J. (2014). Tracing value-added and double counting in gross exports. American Economic Review, 104(2), 459-494. https://doi.org/10.1257/aer.104.2.459

Kraemer, K. L., Linden, G., \& Dedrick, J. (2011). Capturing value in global networks: Apple's iPad and iPhone. PCIC Working Paper. http://pcic.merage.uci.edu/papers/2011/value_ipad_iphone.pdf

Kroese, L., Kok, S., \& Parlevliet, J. (2015). Beleidsonzekerheid in Nederland. Economisch Statistiche Berichten, 100(4715), 464-467. https://www.policyuncertainty.com/netherlands_monthly.html

Leontief, W. W. (1936). Quantitative input and output relations in the economic systems of the United States. Review of Economics and Statistics, 18(3), 105-125. https://doi.org/10.2307/1927837

Li, J. (2021). Economic policy uncertainty, contracting frictions and imports sourcing decisions. Economics Letters, 200, 109772. https://doi.org/10.1016/j.econlet.2021.109772

Liu, Q., \& Qiu, L. D. (2016). Intermediate input imports and innovations: Evidence from Chinese firms' patent filings. Journal of International Economics, 103, 166-183. https://doi.org/10.1016/j.jinteco.2016.09.009

Novy, D., \& Taylor, A. M. (2020). Trade and uncertainty. Review of Economics and Statistics, 102(4), 749-765. https://doi.org/10.1162/rest_a_00885

Pierce, J. R., \& Schott, P. K. (2016). The surprisingly swift decline of US manufacturing employment. American Economic Review, 106(7), 1632-1662. https://doi.org/10.1257/aer.20131578

Roberts, M. J., \& Tybout, J. R. (1997). The decision to export in Colombia: An empirical model of entry with sunk costs. American Economic Review, 87(4), 545-564. https://www.jstor.org/stable/2951363

Sharma, C., \& Paramati, S. R. (2021). Does economic policy uncertainty dampen imports? Commodity-level evidence from India. Economic Modelling, 94, 139-149. https://doi.org/10.1016/j.econmod.2020.09.019

Shen, L., \& Silva, P. (2018). Value-added exports and U.S. local labor markets: Does China really matter? European Economic Review, 101, 479-504. https://doi.org/10.1016/j.euroecorev.2017.10.009

Shi, B. (2016). Internet and international trade--empirical evidence based on bilateral and bidirectional hyperlinks data. Economic Research Journal, 51(05), 172-187.

Silva, J. M. C. S., \& Tenreyro, S. (2006). The log of gravity. Review of Economics and Statistics, 88(4), 641-658. https://doi.org/10.1162/rest.88.4.641

Stokey, N. L. (2016). Wait-and-see: Investment options under policy uncertainty. Review of Economic Dynamics, 21, 246265. https://doi.org/10.1016/j.red.2015.06.001

Taglioni, D., \& Zavacka, V. (2012). Innocent bystanders: How foreign uncertainty shocks harm exporters. Policy Research Working Paper, No.6226. https://openknowledge.worldbank.org/handle/10986/12063; https://doi.org/10.1596/18139450-6226

Tam, P. S. (2018). Global trade flows and economic policy uncertainty. Applied Economics, 50(34-35), 3718-3734. https://doi.org/10.1080/00036846.2018.1436151

Timmer, M. P., Dietzenbacher, E., Los, B., et al. (2015). An illustrated user guide to the world input-output database: The case of global automotive production. Review of International Economics, 23(3), 575-605. https://doi.org/10.111 $1 /$ roie. 12178

Timmer, M. P., Los, B., Stehrer, R., et al. (2013). Fragmentation, incomes and jobs: An analysis of European competitiveness. Economic Policy, 28(76), 613-661. https://doi.org/10.1111/1468-0327.12018

Tinbergen, J. (1962). Shaping the world economy. New York: Twentieth Century Fund.

Wang, Z., Wei, S. J., \& Zhu, K. (2013). Quantifying international production sharing at the bilateral and sector levels. NBER Working Paper, No.19677. https://doi.org/10.3386/w19677

Wang, Z., Wei, S. J., \& Zhu, K. (2015). Gross trade accounting method: Official trade statistics and measurement of the global value chain. Social Sciences in China, (09), 108-127+205-206. 
Xing, Y., \& Detert, N. (2010). How the iPhone widens the United States trade deficit with the People's Republic of China. ADBI Working Paper, No.257. https://doi.org/10.2139/ssrn.1729085

Zalla, R. (2017). Economic policy uncertainty in Ireland. Atlantic Economic Journal, 45(2), 269-271. https://doi.org/10.10 07/s11293-017-9536-8

\section{Authors' biographies}

Tingting Zhao is a Ph.D. candidate at the School of International Trade and Economics at University of International Business and Economics, China. Her major is international trade. Her present research interests are in the field of ecommerce and international trade.

The article has been reviewed. Received in July 2020; accepted in February 2022. 